\title{
The Influence of Leadership Style on Organizational Performance at TumaKavi Development Association, Tamale, Northern Region of Ghana
}

\author{
John Yaw Akparep ${ }^{1}$, Enock Jengre ${ }^{2}$, Alisa Afusah Mogre ${ }^{3}$ \\ ${ }^{1}$ Department of Management Studies, School of Business and Law, University for Development Studies, Wa Campus, Wa, Ghana \\ ${ }^{2}$ Legal Resources Centre, Accra, Ghana \\ ${ }^{3}$ North Breeze Leadership, Tamale, Ghana \\ Email: ^jakparep@uds.edu.gh
}

How to cite this paper: Akparep, J. Y., Jengre, E., \& Mogre, A. A. (2019). The Influence of Leadership Style on Organizational Performance at TumaKavi Development Association, Tamale, Northern Region of Ghana. Open Journal of Leadership, $8,1-22$.

https://doi.org/10.4236/oj1.2019.81001

Received: January 16, 2019

Accepted: March 15, 2019

Published: March 18, 2019

Copyright $\odot 2019$ by author(s) and Scientific Research Publishing Inc. This work is licensed under the Creative Commons Attribution International License (CC BY 4.0).

http://creativecommons.org/licenses/by/4.0/

(c) (i) Open Access

\begin{abstract}
Leadership is one of the key driving forces for improving a firm's performance. It is assumed that the kind of leadership style employed in an organization has an impact on its overall performance. The study examined the leadership style practiced at TumaKavi Development Association (TKDA) in Northern Region of Ghana and its effect on its organizational performance. Qualitative case study design was employed. Purposive sampling was adopted to sample a total sample size of 11 respondents representing $65 \%$ of the total staff population. The study established that TKDA majorly uses democratic leadership style in its operations. It also discovered that the democratic leadership style being practiced has had an appreciable influence on the operations and performance of the organization. The results of this study also revealed that there is strong relationship between leadership style and organizational performance of TKDA. As the strength of the organization dwells much on democratic style of leadership, it is recommended that management of the organization applies more of that and mix it with other leadership styles where necessary for the organization to wax stronger within its industry.
\end{abstract}

\section{Keywords}

Leadership, Influence, Democratic Style, Organizational Performance

\section{Introduction}

There has been significant theoretical and empirical work carried out on orga- 
nizational performance across the globe. For some decades now, how leadership impacts on organizational performance has gained prominence among academics and practitioners working in the area of leadership (Al Khajeh, 2018; Bhargavi \& Yaseen, 2016; Igbaekemen \& Odivwri, 2015; Giambatista, 2004; Rowe et al., 2005). This is premised on the notion that a style of leadership of an organization has a correlation with organizational performance (Rowe et al., 2005). The style of leadership adopted is considered by some researchers to be particularly important in achieving organizational goals, and in evoking performance among subordinates (Sadia \& Aman, 2018; Klein et al., 2013; Berson et al., 2001; Zacharatos et al., 2000; Barling et al., 1996). Organizations undergo rapid changes daily as a result of diverse factors. Some of these factors are external such as competition, global market trends and technological changes. Some of the changes over time also occur within the organizations themselves. Examples are employee motivation, innovation, organizational culture and human resource strength (Haque et al., 2015; Igbaekemen \& Odivwri, 2015; Bass \& Riggio, 2006). All these tend to affect the performance of these organizations. One key factor that also has the potential to largely affect an organization's performance is its leadership (Ng'ethe et al., 2012; Jeremy et al., 2012).

The role of leaders in ensuring excellent organizational performance cannot be over emphasized. Adequate motivation, suitable work environment, compensation, efficient communication between managers and subordinates play an important role in promoting this goal. Planning and organization of work is also very crucial. It has been argued by some researchers that the most common problems affecting organizational performance in business and other institutions are poor attitude to work among workforce, inefficiency as well as ineffectiveness of leaders in most places, though others share a contrary view (Haque, Faizan, \& Cockrill, 2017). Leadership style practiced by an organization has an impact on the success or otherwise of its operations. Leadership style in an organization is one of the factors that play significant role in enhancing or retarding the interest and commitment of the individuals in the organization (Bhargavi \& Yaseen, 2016; Obiwuru et al., 2011).

Performance continues to be a key issue among organizational researchers and employees are bound to perform well where they are treated well (Haque, Faizan, \& Cockrill, 2017; Barney, 1997). Javier (2002) has asserted that performance is equivalent to the famous 3Es (economy, efficiency, and effectiveness) of a certain program or activity. However, according to Daft (2000), organizational performance is the organization's ability to attain its goals by using resources in an efficient and effective manner. Quite similar to Daft (2000), Ricardo \& Wade (2001) rather define organizational performance as the ability of the organization to achieve its goals and objectives.

Organizational theorists contend that effective leadership is one of the most important contributors to overall organizational success (Weber, 2009; Daft, 2000; Pettinger, 2000; Barney, 1997; Kotter \& Heskett, 1992; Ricardo \& Wade, 
2001). Many leadership theories have been proposed in the last fifty years, which are claimed to have influenced the overall effectiveness of organizations where they have been employed. In the competitive world with technological changes within the business environment, it is vital that organizations employ leadership styles that enable them to survive in a dynamic environment (Maritz, 1995; Bass, 1997). Without leadership, the probability of mistakes occurring increases and the opportunities for success become more and more reduced. The role of a leader is vital for the survival and progress of an organization. Al Khajeh (2018) and Bhargavi \& Yaseen (2016) in their study on leadership and organizational performance suggest that the role of leadership is critically important for an organization to achieve a high level of performance.

It is contended that organizations do not only exist for survival, but also to sustain their existence by improving performance. In order to meet the needs of the highly competitive markets, organizations must continually increase performance by adopting the appropriate leadership style. Leadership style is a key determinant of the success or failure of any organization. Leaders influence, direct, and motivate others to perform specific tasks and also inspire subordinates. Literature suggests that the role of leadership is critically important for achieving the performance of organizations. To this end, some studies argue that effective leadership role in increasing organizational performance are mixed (Uchenwamgbe, 2013; Hambrick, 2007; Katz \& Kahn, 1978).

The research examined the operations of TumaKavi Development Association (TKDA), a regional Non-Governmental Organization (NGO) working in thirty-two communities in four districts of the Northern Region of Ghana. It is believed that the organization has achieved some feats in its operations over the years. However, not much is known about the kind of leadership style(s) being employed by management of the organization resulting to this level of performance. Premised on this, the study aimed to examine the leadership style(s) practiced at TumaKavi Development Association and its effect on the performance of the organization.

\section{Literature Review}

\subsection{Understanding Leadership}

Leadership has been a topic of study for social scientists for much of the twentieth century, yet there has been no consensually agreed-upon definition of it (Jyoti \& Bhau, 2015; Sofi \& Devanadhen, 2015; Xu \& Wang, 2008; Bass, 1990). Many authors have studied this phenomenon, and some have argued that there is no conscious definition of what leadership is, no dominant paradigm for studying it, and little agreement regarding the best strategies for developing and exercising it (Bennis, 2007; Hackman \& Wageman, 2007; Vroom \& Jago, 2007). However, Ngodo (2008) views leadership as a form of direction in which a person can give to a group of people he steers affairs in such a way that will influence the behavior of another individual, or group. Ngodo (2008) perceives lea- 
dership to be a reciprocal process of social influence, in which leaders and subordinates influence each other in order to achieve organizational goals. Sun (2002) defines leadership as the process of influencing people so that they make an effort by their own will and enthusiasm towards obtaining the group's goals.

Leadership is a critical management skill, involving the ability to encourage a group of people towards a common goal. Leadership focuses on the development of followers, their needs and building their capacity (Klein et al., 2013). It is imperative for managers occupying leadership positions to focus on the development of value system of employees, their motivational level and moralities with the development of their skills (Uchenwamgbe, 2013; Ismail et al., 2009). This approach will essentially help followers achieve their goals as they work in the organizational setting. As posited by Khan et al. (2014), followers will be encouraged to be expressive and adaptive to new and improved practices and changes in the environment.

According to Michael (2010) leadership has a direct cause-effect relationship upon organizations and their success. Leaders determine values, culture, change tolerance and employee motivation. They shape institutional strategies including their execution and effectiveness. It should be stressed that leaders can be found at any level of an institution and are not exclusive to management. Successful leaders do, however, have one thing in common. They influence those around them in order to reap maximum benefit from the organization's resources, including its most vital and expensive human resources/capital. This success can only be achieved and probably sustained in organizations where appropriate leadership style or styles are employed at a given time. Leadership is also a process which involves the use of non-coercive influence to shape a group or organizational goals, motivate behaviour towards achieving the goals as well as define the group's culture (Northouse, 2009).

Despite the variations in the definitions, there are at least three important implications of these definitions. Firstly, leadership is a process engaged in by certain individuals (leaders). It is an ongoing activity in an organization. Secondly, it involves other people in the form of subordinates or employees who by their willingness are influenced by the leader. Therefore, the subordinates formalize the leader's authority by making leadership process possible. Thirdly, the aim of leadership is the accomplishment of a goal and objectives. A seemingly endless variety of definitions have been developed, and there is a common thread which runs through all the definitions and that is the concept of influence. Leaders therefore influence others to help accomplish group and organizational objectives. However, it should be noted that the use of appropriate leadership style at a given time is a conduit for organizational success.

\subsection{Leadership Styles}

Any organization which employs appropriate leadership style(s) couple with other factors in its operation has a higher probability of achieving its organizational goals. An organizational leadership style(s) go(es) a long way to influence 
the culture of the organization. This in turn directly or otherwise influences the performance of the organization (Haque et al., 2015; Klein et al., 2013). Leadership is the life blood of any organization and its importance cannot be underestimated. According to Armstrong (2012), a leadership style is the approach used by managers to exercise their leadership function. This is seen to be a particular behavior a leader in an organization employs to motivate employees towards the achievement of a defined objective of the organization (Haque et al., 2015; Igbaekemen \& Odivwri, 2015; Ng'ethe et al., 2012). Leadership style plays an important role in the organizations of today. As defined by Mullins (2000), leadership style is the way and manner in which a manager or supervisor chooses to act towards his employees or subordinates and the way the leadership function is being carried out by them (Xenikou, 2017). Researchers in the area of leadership suggest that no one leadership style is better than the other but that styles are dependent on some factors (Armstrong, 2012; Adair, 2003). They indicate such factors to include the type of organization, nature of the task, characteristics of the individuals in the leader's team, the group the leader leads as a whole and more importantly, the personality of the leader. To them therefore, there is not one leadership style that is considered best at all times as a particular situation would demand one or a combination of different leadership styles.

Leaders should be able to know how their leadership skills influence their followers as it has an impact on the followers being supportive of them or not (Saleem, 2015; Sethuraman \& Suresh, 2014). This can have an impact on employee behaviour to support their leaders; followers or employees who do not have support for their leaders can be prone to dissatisfaction which could arouse an intention of an employee to leave. Some authors have argued that leadership styles can affect an employee's job satisfaction level and job satisfaction is an outcome of leadership style. This can negatively be associated with the intention of the employee to leave the organization (Khan et al., 2014; Welty Peachey et al., 2014). This suggests that leadership style or behaviour has an impact on job satisfaction and an employee's desire and intention to leave an organization or otherwise. As indicated by Vandenberghe \& Bentein (2009), before an employee considers leaving an organization, such an employee will first assess (Tummers \& Knies, 2016) the position of his/her relationship with the organization, among other factors. It is noteworthy to stress that appropriate leadership style employed in a given time regardless of low remuneration could still motivate an employee to put up his/her best in the organization. This assessment according to Welty Peachey et al. (2014) could include the level of attachment of the employee to the organization and the leader. In the case where this relationship is lessened or negatively affected, the employee has the tendency to leave such an organization. Leadership style reflects what leaders "do" and how they "behave". There are many dimensions to leadership and many possible ways of describing leadership styles such as dictatorial, unitary, bureaucratic, charismatic, consultative and participative. However, a collection of some leadership styles in contemporary businesses which are still pervasive in contemporary times are classi- 
fied as follows.

\subsection{Autocratic Leadership}

An autocratic leader is seen as the one who is very conscious of his position and has little trust or faith in the subordinates (Luftman, 2004). Autocratic leaders are classic and bossy in nature. Such leaders desire that their subordinates work according to what they dictate (Al Khajeh, 2018). Basically, autocratic leaders retain the decision-making rights with them (Obiwuru et al., 2011).

An autocratic leader feels that remuneration advanced to employees for work done is a just reward and it is only the reward that can motivate an employee. This style of leadership is characterized by individual control over all decisions and little input from group members. A study conducted indicates that an autocratic/authoritarian leader is characterized as being arbitrary, controlling, power-oriented, coercive, legitimate, punitive and with a closed mind (Al Khajeh, 2018; Iqbal et al., 2015; Bass \& Bass 2009). Such leaders stress loyalty and obedience and are defined as those who make decisions alone and demand strict adherence to rules. The decision-making process is centralized; autocratic leaders take full responsibility for decisions and control of their followers' performance. Praise and criticism of followers play a significant role in autocratic leadership. Autocratic leaders typically make choices based on their own ideas and judgments and rarely accept advice from followers. Autocratic leadership involves absolute, authoritarian control over a group. Other characteristics of autocratic leadership include: little or no input from group members, leaders make the decisions, group leaders dictate all the work methods and processes and group members are rarely trusted with decisions or important tasks.

Armstrong (2012) suggests that autocratic leadership may be useful in situations of emergency, in cases where homogenous work force is involved and where the leader is wise, just and has considerable understanding of the followers. In such circumstances, special action may be needed to avert a potential mishap. Among some shortcomings of autocratic leadership is the inability of the subordinates to develop pride of accomplishment, denial of personal development or satisfaction from self-actualization, and it also antagonizes human beings and wipes the organization of lasting loyalty and co-operation. Indeed, the autocratic style is characterized by an "I tell" philosophy. That is, an autocratic leader tells staff members what to do. Even though this approach can give a business a clear direction, however, it may also lead managers to undervalue or ignore input from team members (Obiwuru et al., 2011). Nonetheless, an autocratic approach is appropriate in some situations. It is valuable when the business faces a crisis or when an urgent problem arises that requires an immediate response (Bhargavi \& Yaseen, 2016). There is no shared vision and little motivation beyond coercion. Commitment, creativity and innovation are typically eliminated by autocratic leadership (Al Khajeh, 2018). In fact, most followers of autocratic leaders can be described as bidding their time, waiting for the inevita- 
ble failure this leadership produces and the removal of the leader that follows (Iqbal et al., 2015; Michael, 2010).

\subsection{Democratic Leadership}

Democratic leadership, also referred to as participative leadership, is a type of leadership style in which members of the group take a more participative role in the decision-making process. This style of leadership dwells on performance and people (Bhargavi \& Yaseen, 2016; Puni et al., 2014). Democratic leadership style encourages employees to participate in the decision making process of the organization (Nwokocha \& Iheriohanma, 2015). According to Puni et al. (2014), decision making in a democratic system is not centralized and high performance is recognized and rewarded. Nwokocha \& Iheriohanma (2015) on the other hand suggest that there is potential for poor decisions to be made by the subordinates as a result of the leader depending on the contributions made by the employees or subordinates. This can be said to have a negative impact on the organization and can also instigate turnover intention in employees. It is therefore expected that brainstorming of ideas and collective decisions are arrived at by all concerned.

The democratic leadership sounds good in theory but it is often bogged down in its slow decision making process and the results which could seem workable would always require a lot of time and effort (Nwokocha \& Iheriohanma, 2015). The democratic leader allows for decision making to be shared by the leader and the group. Criticisms and praises are objectively given and a feeling of responsibility is developed within the group. Kotter (1995) argued that this form of leadership is claimed to be earliest amongst all other leadership style. The leader discusses with subordinates before he issues general or broad orders from which subordinates feel free to act on (Bhargavi \& Yaseen, 2016). The superior allows the subordinates opportunity to use their initiative and make contributions. The leaders also offer support to the subordinates in accomplishing task. Characteristics of democratic leadership include: the fact that group members are encouraged to share ideas and opinions, even though the leader retains the final say over decisions, members of the group feel more engaged in the process and creativity is encouraged and rewarded. Democratic leadership yields a lot of benefits. Subordinates are encouraged to share their thoughts; it can lead to better ideas and more creative solutions to problems (Sadia \& Aman, 2018). Employees also feel more involved and committed to projects, making them more likely to care about the end results. It is perceived that democratic leadership style leads to higher productivity among group members.

There are however some downsides of democratic leadership. In situations where roles are unclear or time is of the essence, democratic leadership can lead to communication failures and uncompleted projects. In some cases, group members may not have the necessary knowledge or expertise to make quality contributions to the decision-making process. Democratic leadership works best 
in situations where group members are skilled and eager to share their knowledge. It is also important to have plenty of time to allow people to contribute, develop a plan and then vote on the best course of action.

\subsection{Laissez-Faire Style of Leadership}

Laissez faire is a French phrase which means "let it be" and it is also known as the "hands off style" (Nwokocha \& Iheriohanma, 2015: p. 194). According to Gill (2014), it means leaving subordinates to complete tasks and jobs in the way they choose without adherence to any strict policies or procedures. Bass (1985) describes the laissez faire leadership style as one in which the leader has no belief in his own ability to supervise. He further states that the leader has no clear set goals towards how they may work, does not help the group in making decisions and so leaves too much responsibility with subordinates. According to Puni et al. (2014), the laissez-faire leader avoids controlling his employees and so only relies on the few available employees who are loyal to get a task done.

It is argued that laissez faire leaders do not believe in employee development as they believe that employees can take care of themselves (Puni et al., 2014). This leadership style cannot be said to be operational in the banking sector or Non-Governmental Organizations which require that both the leader and subordinates have an input in the decision making process and completion of tasks to ensure the success of the organization. This is defined as a style of leadership where leaders refuse to make decisions, are not available when needed, and choose to take no responsibility for their lack of leadership ability. Laissez-faire leaders do not use their authority and avoid taking actions. It is considered a passive and ineffective form of leadership. This style favors the installation of a relaxed working atmosphere; it brings down morale and reduces efficiency of the group. With this type of leadership style, leaders attempt to pass the responsibility of decision making process to the group. The group is loosely structured as the leader has no confidence in his leadership ability. A laissez-faire leader may either not intervene in the work affairs of subordinates or may completely avoid responsibilities as a superior and is unlikely to put in effort to build a relationship with them. Laissez-faire style is associated with dissatisfaction, unproductiveness and ineffectiveness (Deluga, 1992). This however, is debatable. Decision making under this style of leadership is performed by whoever that is willing to accept it.

\subsection{Leadership Styles and Organizational Performance}

It is considered that an organization's leadership undoubtedly has a strong bearing on its performance, employee job satisfaction and employee commitment. Some researchers have argued that leaders motivate and help their employees to be competitive by using effective leadership styles (Bhargavi \& Yaseen, 2016; Bass \& Riggio, 2006; Luftman, 2004). Relationship between leadership style and organizational performance has been topical in recent times. Re- 
search shows that leadership style has a significant relationship with organizational performance, and different leadership styles may have a positive correlation or negative correlation with the organizational performance, depending on the variables used by researchers (Wang et al., 2010). Therefore, the leader's use of effective leadership style(s) is imperative to promoting standards of excellence in the professional development of the members of the organization.

McGrath \& MacMillan (2000) contend that there is significant relationship between leadership styles and organizational performance. Effective leadership style is seen as a potent source of managing development and sustained competitive advantage (Al Khajeh, 2018). Leadership style helps the organization to achieve its current objectives more efficiently by linking job performance to valued rewards and by ensuring that employees have the resources needed to get the job done. Sun (2002) compared leadership style with leadership performance in schools and enterprises and found that leadership style had a significantly positive correlation with the organizational performance in both schools and enterprises. According to Kotter (1995), without leadership, the probability of mistakes occurring increases and the opportunities for success become more and more reduced. In this way, leadership, together with stimulants and incentives, promotes people's motivation towards achieving common goals, having a relevant role in the processes of forming, transmitting and changing organizational culture (Senge, 1990).

Assuming the essence of leadership is influence, leadership could broadly be defined as the art of mobilizing others to want to struggle for shared aspirations (Druskat et al., 2003). However, it could be argued this "influence, mobilization and struggle" are of little value in an organizational context unless the effects ultimately yield an outcome in line with the "shared aspiration" for leadership to be deemed successful. Leadership is all about results. Creating results in today's ever changing and increasingly competitive world requires a very different kind of leadership from what was studied in the past (Haque et al., 2015). While leaders in the past managed perhaps complex organizations, this was in a world of relative stability and predictability. In today's globalized world, with organizations coping with rapidly changing environments, leaders face a new reality. Working in flexible contexts and connected by real-time electronic communication, increasingly mobile employees have themselves become the critical resource of their organizations (Wang et al., 2010). What is now needed are leaders who simultaneously can be agents of change and centers of gravity, keep internal focus and enable people and organization to adapt and be successful (Jyoti \& Bhau, 2015; Sofi \& Devanadhen, 2015).

\subsection{Overview of TumaKavi Development Association (TKDA)}

TumaKavi Development Association (TKDA) started in 1983 as a women's group in a rural community called "Moglaa" in the Savelugu/Nanton District, Northern Region of Ghana. The formation of TumaKavi became necessary as a 
result of the 1983 drought in Ghana which worsened the plight of women and children. Essential commodities were scarce and food prices were high. This made it difficult for the average family in the village to cope with the personal hygiene and nutritional needs of the family. A Public health nurse who engaged the women in hygiene and nutrition education solicited for funding from MATCH Canada. The women broke into new grounds of acquiring their own farmland to cultivate groundnuts; they also owned and operated their own grinding mill through a support from Canadian University Students Organization. Apart from the economic gains made by the women and their families, they also gained confidence and it improved relationships between them and their families. Generally, the project brought improvement in economic and nutritional status of children and increased the social status of women. This Women's Group later grew into TumaKavi Development Association (TKDA) with the Public health nurse eventually becoming the Executive Director after retiring from her job in 2012.

TumaKavi has thus evolved from a community based women's group to a regional Non-Governmental Organization (NGO); working in thirty-two communities in four districts of the Northern Region. Inter alia, it signed a partnership agreement with Christian Children's Fund of Canada in 1996 and the Zogu Area Child Care and Family Helper Project, a child sponsorship project, which commenced in 1997 at Zogu. TumaKavi also signed partnership with ISODEC on Reproductive Health in 2002 for 12 communities in the Zabzugu/Tatale District. The organization has a mission to assist needy people especially women and children improve the quality of their living standard through education of children especially the girl child, primary health care, nutrition education, water and sanitation and micro development enterprise. It aims at improving the lives of deprived families and communities in Northern Ghana through sustainable development projects in child education, health and nutritional status of families, income generation of women, improved water and sanitation conditions.

\section{Methodology}

The study employed qualitative case study design to collect and analyse the data. It involved in-depth interviews (one-on-one interviews) in order to fully understand the kind of leadership style practiced at TumaKavi Development Association (Akparep et al., 2017; Creswell, 2007). This approach has some promising directions for organizational direction and performance. The employees of the organization including the Executive Director formed the research respondents of the study.

The study was conducted using both primary and secondary sources of data. Interviews formed the basis for the primary sources of data. A semi-structured interview guide was designed for the respondents. The employees of the organization were put into groups according to their function or department at the organization. Focus group discussions were then held with the employees and 
management of the organization. Respondents' opinions were solicited on the organization's leadership style and its impact on the performance of the organization. This way, the researchers had control over the line of questioning while the respondents were given adequate space to provide historical and detailed information where necessary (Owusu-Sekyere et al., 2018; Creswell, 2007; Sekaran, 2003). Also, in order to fully understand the issues being investigated, the one-on-one story-telling interview approach was adopted as it is an effective tool which offers researchers an opportunity to get in-depth information regarding the phenomenon under investigation (Maxwell, 2005).

The interview guide designed comprised a leadership style assessment (Northouse, 2009). This was designed to measure basically the three common leadership styles; democratic, autocratic and laissez-faire. The other component of the interview guide consisted of a number of questions to provide data on how the identified leadership style practiced had impacted the organisation. Purposive sampling approach under the non-probability sampling technique was employed to select a total sample size of 11 respondents representing $65 \%$ of the total population for the study. The purposive sampling approach was a useful technique for soliciting the required information from the head of the organization (see: Maxwell, 2005 cited in Akparep et al., 2017). Journal articles, text books, library sources of information and various reports of the organization were reviewed which served as secondary sources of data for the study.

Data collected with the semi-structured interview guide were imported into Statistical Package for Social Sciences (SPSS) for analysis. The data was presented in a manner that allowed for easy analysis and testing using SPSS. Once the data was imported into a SPSS spreadsheet, from the Microsoft excel spread sheet, the researchers proceeded to calculate the necessary leadership scores as per the respective scoring keys provided along with the interview guide, available to the respondents. Again, all the focus group discussions were audio-recorded with the respondents' permission. These audio tapes were transcribed verbatim and added to other field notes and analyzed manually using hand coding and highlighter pens to color important texts. Themes so identified were then categorized into major themes with sub-themes for each of the major themes. As Maxwell (2005) has advised, this is a very useful approach to qualitative data analysis as it provides great opportunities for researchers to carefully organize volumes of qualitative data into insightful findings (Owusu-Sekyere et al., 2018).

\section{Analysis and Discussion of Results}

\subsection{Ages of Respondents}

Table 1 shows that majority of the staff were of a youthful age whilst a few were beyond 35 years of age as illustrated below.

\subsection{Number of Years in the Organization and Job Categories}

From Table 2, it indicates that $54 \%$ of the respondents had served in the organ- 
ization between three and five years whilst $27 \%$ had been with the organization for one to three years. They therefore had a relatively good knowledge of the organization and understood the trends well as the Table 2 depicts.

\subsection{Job Titles and Categories of Respondents}

Table 3 indicates job titles of the categories of the respondents as represented below. There was at least one respondent from each of the departments and this ensured a fair representation of the general staff of TKDA.

\subsection{Indicators of Performance of TKDA}

Respondents were asked on the indicators they would consider in assessing the performance of TKDA. Six different indicators were presented namely; achievement of goals and targets, scope and depth of projects, partnerships, funding opportunities, staff strength and turnover and awards. Majority of the respondents agreed that all were indicators of TKDAs performance but the one mostly used was the achievement of goals and targets which are usually outlined in Annual Operating Plans.

Table 4 highlights the trend of the performance of the organization under study within the years 2012 to 2017. Most of the respondents felt that the organization had an increasing trend of 36\% of performance in 2017 and an equally high percentage of them felt that TKDA has had a stable trend of $36 \%$ of performance over the years. There were two respondents who did not indicate their views and 1 (9\%) felt that the trend of performance was unpredictable.

Table 1. Age of respondents.

\begin{tabular}{ccc}
\hline Age Range & $\begin{array}{c}\text { Frequency of } \\
\text { Respondents }\end{array}$ & $\begin{array}{c}\text { Percentage of } \\
\text { Respondents (\%) }\end{array}$ \\
\hline $25-34$ & 9 & 81.82 \\
Grand Total & 2 & 18.18 \\
\hline
\end{tabular}

Source: Authors Construct, 2018.

Table 2. Number of years worked at TKDA.

\begin{tabular}{ccc}
\hline $\begin{array}{c}\text { Number of } \\
\text { Year(s) }\end{array}$ & $\begin{array}{c}\text { Frequency of } \\
\text { Respondents }\end{array}$ & $\begin{array}{c}\text { Percentage of } \\
\text { Respondents (\%) }\end{array}$ \\
\hline $\begin{array}{l}3-5 \text { years } \\
\text { - years }\end{array}$ & 3 & 27.27 \\
$5-10$ years & 6 & 54.55 \\
Grand Total & 2 & 18.18 \\
\hline
\end{tabular}

Source: Authors Construct, 2018. 
Table 3. Job titles and categories of respondents.

\begin{tabular}{ccc}
\hline Job Title/Category & Frequency of Respondents & Percentage of Respondents (\%) \\
\hline Admin/Finance Officer & 1 & 9.09 \\
Credit Officer & 1 & 9.09 \\
Finance Officer & 1 & 9.09 \\
Office Assistant & 1 & 9.09 \\
Program Manager & 1 & 9.09 \\
Program Officer & 3 & 27.27 \\
Sponsorship Assistant & 3 & 27.27 \\
Grand Total & 11 & 100 \\
\hline
\end{tabular}

Source: Authors Construct, 2018.

Table 4. Trend of organizational performance over 2012 to 2017.

\begin{tabular}{ccc}
\hline $\begin{array}{c}\text { Trend of Organisation's } \\
\text { Performance }\end{array}$ & Frequency of Respondents & Percentage of Respondents (\%) \\
\hline Increasing & 4 & 36 \\
Stable & 4 & 36 \\
Unpredictable & 1 & 9 \\
No Response & 2 & 18 \\
Grand Total & 11 & 100 \\
\hline
\end{tabular}

Source: Authors Construct, 2018.

The study found out that the $72 \%$ (36\% for increasing and $36 \%$ for stable) suggested that the trend was either increasing or stable mentioned factors like increased funding and grants from donors, projects being executed on schedule, increase in number of project beneficiaries as indications of their views. Meanwhile the only one respondent who felt the trend was unpredictable indicated that there were inconsistencies (monthly fluctuations) in their salaries in relation to what they were initially offered.

Furthermore, respondents were asked what factors they felt were responsible for this increasing or stable trend of organizational growth. Among the factors mentioned were; hard work, mutual respect between all staff, effective teamwork, good leadership, the introduction of performance-based funding by their main donor (CCFC), improved donor support and relationship. With regards to the issue of unpredictability, the respondents felt that the inconsistent salaries were as a result of competition from similar organizations that had stronger capacities than TKDA and therefore attracting potential donors. This could be said to be in line with Welty Peachey et al. (2014) findings.

\subsection{Leadership Style Employed in TumaKavi Development Association (TKDA)}

The first part of the questionnaire contained a model of assessment that used a list of questions and a scoring system to determine which leadership style was 
employed in the organization by the Executive Director. It was designed to measure three common styles of leadership; authoritarian, democratic and laissez-faire. The scores were computed as indicated in Table 5 below.

1) Sum of responses on items $1,4,7,10,13$, and 16 (authoritarian leadership).

2) Sum of responses on items 2, 5, 8, 11, 14, and 17 (democratic leadership).

3) Sum of responses on items $3,6,9,12,15$, and 18 (laissez-faire leadership). In Table 5 were respondents' scores for the various questions.

By comparing the scores in the manner illustrated in Table 5, one is able to determine which leadership style is most dominant and least dominant.

1) Sum the responses on items $1,4,7,10,13$, and 16 (authoritarian leadership).

2) Sum the responses on items $2,5,8,11,14$, and 17 (democratic leadership).

3) Sum the responses on items 3, 6, 9, 12, 15, and 18 (laissez-faire leadership).

Outcome of Assessment: Based on respondents' scores for the various statements, the average of the various scores for each leadership style is represented below:

Authoritarian Leadership-16

Democratic Leadership-21

Laissez-Faire Leadership-18

From the scores on Table 5 above, majority of the respondents ( 21 scores) agreed that democratic leadership is the most dominant style of leadership practiced by the leadership of TKDA. A number of respondents (18 scores) also felt that the leader employed the laissez-faire type of leadership whilst 16 scorings were of the opinion that authoritarian leadership was the style of leadership practiced in TKDA. This analysis of the different ratings is in consonance with Armstrong (2012) and Adair's (2003) argument that no one leadership style is better than the other but that the styles are dependent on a given situation.

It is worth noting that the same assessment was completed by the Executive Director and an analysis of her scores showed that the democratic style was the most dominant, followed by the laissez-faire with the authoritarian style being the least dominant.

\subsection{Leadership Style and Organizational Performance at TKDA}

In drawing the line and assessing as to whether there exists any form of relationship between leadership style practiced at the TumaKavi Development Association and its performance resonated in Table 6.

Findings from Table 6 indicated that $82 \%$ forming majority of the respondents established a relationship between leadership style and organizational performance. $73 \%$ of them reported a positive relationship between the leadership style employed at the organization and how the organization has progressed. Respondents indicated that due to the leadership style of management, that is majorly democratic, there was a high level of staff involvement in management decision making process. This supports Bhargavi \& Yaseen (2016) and 
Table 5. Respondents' scores on statement on leadership.

\begin{tabular}{|c|c|c|c|c|c|c|c|c|c|c|c|c|}
\hline S/N & Statement on Leadership & A & B & $\mathrm{C}$ & $\mathrm{D}$ & $\mathbf{E}$ & F & G & $\mathrm{H}$ & I & $\mathrm{J}$ & $\mathrm{K}$ \\
\hline 1 & $\begin{array}{l}\text { The leader makes all } \\
\text { the major decisions }\end{array}$ & 4 & 4 & 2 & 4 & 3 & 5 & 2 & 2 & 4 & 3 & 2 \\
\hline 2 & $\begin{array}{l}\text { You receive guidance from } \\
\text { the leader on what to do and how }\end{array}$ & 4 & 4 & 4 & 4 & 4 & 5 & 2 & 1 & 4 & 5 & 4 \\
\hline 3 & $\begin{array}{l}\text { The leader allows group members } \\
\text { to make their own decisions even } \\
\text { in complex situations }\end{array}$ & 2 & 2 & 2 & 3 & 2 & 2 & 2 & 4 & 4 & 4 & 3 \\
\hline 4 & $\begin{array}{c}\text { You are given rewards to } \\
\text { motivate employees to } \\
\text { achieve organizational objectives }\end{array}$ & 1 & 1 & 3 & 3 & 2 & 4 & 1 & 1 & 2 & 2 & 3 \\
\hline 5 & $\begin{array}{l}\text { The leader encourages creativity } \\
\text { and people are often highly } \\
\text { engaged in projects and decisions }\end{array}$ & 3 & 3 & 4 & 4 & 4 & 4 & 4 & 2 & 4 & 2 & 4 \\
\hline 6 & $\begin{array}{l}\text { The leader gives team members a lot of } \\
\text { freedom in the way they do their work }\end{array}$ & 2 & 2 & 2 & 4 & 4 & 2 & 2 & 2 & 5 & 3 & 4 \\
\hline 7 & $\begin{array}{l}\text { The leader believes most } \\
\text { employees feel insecure about } \\
\text { their work and need direction }\end{array}$ & 3 & 3 & 4 & 2 & 2 & 4 & 3 & 2 & 4 & 1 & 3 \\
\hline 8 & $\begin{array}{l}\text { There's frequent and supportive } \\
\text { communication from the leader } \\
\text { to the rest of the staff }\end{array}$ & 2 & 2 & 4 & 4 & 4 & 3 & 5 & 4 & 5 & 4 & 3 \\
\hline 9 & $\begin{array}{l}\text { You are allowed to } \\
\text { appraise their own work }\end{array}$ & 2 & 2 & 4 & 3 & 4 & 2 & 5 & 4 & 5 & 4 & 3 \\
\hline 10 & $\begin{array}{l}\text { The leader is the chief judge of the } \\
\text { achievements of the team }\end{array}$ & 4 & 4 & 4 & 4 & 4 & 4 & 4 & 5 & 2 & 5 & 3 \\
\hline 11 & $\begin{array}{l}\text { The leader makes the final decision } \\
\text { but includes team members in the } \\
\text { decision making process }\end{array}$ & 4 & 4 & 4 & 4 & 4 & 4 & 4 & 4 & 4 & 5 & 4 \\
\hline 12 & $\begin{array}{l}\text { The leader gives subordinates complete } \\
\text { freedom to solve problems on their own }\end{array}$ & 3 & 3 & 2 & 3 & 2 & 4 & 4 & 2 & 5 & 3 & 3 \\
\hline 13 & $\begin{array}{l}\text { The leader gives all the directions and the } \\
\text { employees are expected to follow }\end{array}$ & 4 & 4 & 2 & 2 & 4 & 2 & 4 & 4 & 4 & 2 & 4 \\
\hline 14 & $\begin{array}{l}\text { The leader encourages group } \\
\text { discussions }\end{array}$ & 3 & 3 & 4 & 4 & 4 & 4 & 5 & 4 & 4 & 2 & 4 \\
\hline 15 & $\begin{array}{l}\text { The leader has very little } \\
\text { authority over staff in the organization }\end{array}$ & 2 & 2 & 5 & 2 & 1 & 2 & 2 & 1 & 5 & 1 & 2 \\
\hline 16 & $\begin{array}{l}\text { The leader does not get too involved } \\
\text { with the team and does not } \\
\text { have discussions with them often }\end{array}$ & 1 & 1 & 1 & 2 & 2 & 3 & 1 & 1 & 2 & 2 & 1 \\
\hline 17 & $\begin{array}{l}\text { The leader gives fair praise and restrains } \\
\text { criticism as much as possible }\end{array}$ & 4 & 2 & 5 & 2 & 3 & 3 & 2 & 2 & 4 & 2 & 2 \\
\hline 18 & $\begin{array}{l}\text { You feel trusted by the leader } \\
\text { to make appropriate decisions } \\
\text { on your own }\end{array}$ & 4 & 3 & 4 & 2 & 2 & 4 & 3 & 4 & 4 & 2 & 3 \\
\hline
\end{tabular}

Source: Authors Construct, 2018. Note: 1) STRONGLY DISAGREE; 2) DISAGREE; 3) NEUTRAL; 4) AGREE; 5) STRONGLY AGREE. 
Table 6. Relationship between leadership style and organizational performance.

\begin{tabular}{ccc}
\hline Relationship & Frequency & Percentage (\%) \\
\hline Yes & 8 & 73 \\
No & 1 & 9 \\
Not Sure & 2 & 18 \\
Grand Total & 11 & 100 \\
\hline
\end{tabular}

Source: Authors Construct, 2018.

Nwokocha \& Iheriohanma (2015) study that democratic leadership style encourages employees to participate in the decision making process of the organization. Leadership also allows for feedback from staff which motivated them. The following was the outcome of an interview on the subject matter:

Here we are somehow fortunate to have a leader who listens to us in decision making. Even though it is democratic leadership style which I think dominates, she also sometimes uses other leadership styles when it becomes necessary. She is dynamic (Focus Group Discussion with employees of TKDA, 2018).

In terms of the negative relationship, $9 \%$ of respondents mentioned that they did not think there were opportunities to be creative and there was a delay in implementation of activities from management. This corroborates the argument that democratic leadership is often bogged down in its slow decision making process and the results which could seem workable would always require a lot of time and effort (Nwokocha \& Iheriohanma, 2015) which may result in low pace of performance and sometimes meeting target.

In terms of whether there was a best leadership model for high organizational performance, 8 respondents representing 73\% answered in the affirmative and explained that a leadership that was democratic, giving freedom to staff to operate, very supportive of staff, providing staff the opportunity to be expressive and creative would yield very high results in terms of performance. As advised by Michael (2010), leadership style of an organization has a direct cause and effect relationship upon organizations and their success. However, 3 respondents (27\%) did not think there was a particular leadership model that was without its weaknesses. They explained that it depended on the type of a leader and how he/she executed his/her duties as indicated in the interview below with the Executive Director:

Our organization majorly practices a democratic leadership style, however, sometimes I can see management employing other leadership styles all in the interest of the organization (Interview with the Leadership of TKDA, 2018).

The excerpts above clearly augment the responses the researchers received from the respondents in respect of the TumaKavi organization using different leadership styles with democratic style dominating in the organization. It therefore goes to stress that it is imperative for organizations to study and adopt appropriate leadership styles at a given time necessary to realize set goals.

Respondents sharing their thoughts on leadership role towards organizational 
performance said that the kind of leadership style practiced by an organization has a bearing on its output. Views expressed by respondents ranged from leadership playing a role of providing staff freedom and room to operate, setting performance targets, providing the potential for staff growth, raising successors through mentorship programmes and more involvement in decision making. Generally, all respondents asserted that leadership is very crucial in the successful performance of an organization.

Because leadership is key to this organization, some of us are privileged to have attended refresher training courses on leadership and this has had an impact on the way TumaKavi runs its operation. Looking at our successes, we can say that it is due to the different leadership styles we practice and the kinds of staff appraisal packages to motivate our staff to put in their best... (Interview with Leadership of TKDA, 2018).

The excerpts give credence to Bass \& Riggio (2006) and Luftman (2004) contention that effective leadership style(s) employed by an organization has/have a bearing on organizational performance.

\section{Limitation and Direction for Future Research}

This study has provided deep insights of the impact of leadership style on the organizational performance of TKDA. The study does not seek to make generalization of its findings as it studied only one organization with a small sample size. This may reduce the applicability and scope of the findings of the research in terms of generalization in other organizations with similar mandate. Hence, future research should focus on widening the scope to cover leadership style and its relationship among different organizations with similar mandate.

\section{Conclusion}

It was established by the research findings that the TumaKavi Development Association majorly uses democratic leadership style in its operations and this has had a significant impact, positively on the organization's performance. The results of this study also revealed that there is strong relationship between leadership style and organizational performance. On the basis of the findings of this study, it was established that leadership style has both positive and negative effects on organizational performance. The study also discovered that leadership of the organization sometimes employs other leadership styles such as authoritarian and laissez-faire where necessary in order to achieve its set goals. Also, the organization's performance has increased as asserted by the majority of the respondents. They felt encouraged to contribute their ideas and opinions, and were more involved and committed to projects. For the few who were of the opinion that performance was declining, decreased donor funding was the cause and not directly a factor of the leadership style. The study therefore concluded that the democratic leadership style practiced at TumaKavi Development Association has significantly improved upon the performances of the organization. 


\section{Recommendation}

As the strength of the organization dwells much on democratic style of leadership, it is recommended that the leadership of the organization continues to employ more of this style of leadership in its operations. Also, it is recommended that the organization should apply other leadership styles where necessary in this dynamic work environment in order for the organization to wax stronger within its industry. Since there is no "one size fits all" style of leadership, it is also recommended that management strives to use various techniques and methods as the situation may demand to encourage staff to work harder to achieve organizational goals and improve performance further.

\section{Conflicts of Interest}

The authors declare no conflicts of interest regarding the publication of this paper.

\section{References}

Adair, J. (2003). Not Bosses but Leaders: How to Lead the Way to Success (3rd ed.). London: Kogan Page.

Akparep, Y. J., Jengre, E., \& Abaamah, D. (2017). Demystifying the Blame Game in the Delays of Graduation of Research Students in Universities in Ghana: The Case of University for Development Students. European Journal of Business and Innovation Research, 5, 34-50.

Al Khajeh, E. H. (2018). Impact of Leadership Styles on Organizational Performance. Journal of Human Resources Management Research, 2018, Article ID: 687849.

Armstrong, M. (2012). Armstrong's Handbook of Management and Leadership: Developing Effective People Skills for Better Leadership and Management (3rd ed.). London: Kogan Page.

Barling, J., Weber, T., \& Kelloway, E. K. (1996). Effects of Transformational Leadership Training on Attitudinal \& Financial Outcomes: A Field Experiment. Journal of Applied Psychology, 81, 827-832. https://doi.org/10.1037/0021-9010.81.6.827

Barney, J. (1997). Firm Resources and Sustained Competitive Advantage. Journal of Management, 1, 99-120.

Bass, B. M. (1985). Leadership and Performance beyond Expectations. New York: Free Press.

Bass, B. M. (1990). Bass \& Stogdill's Handbook of Leadership (3rd ed.). New York: Free Press.

Bass, B. M. (1997). Concepts of Leadership. In R. P. Vecchio (Ed.), Understanding the Dynamics.

Bass, B. M., \& Bass, R. (2009). The Bass Handbook of Leadership: Theory, Research, and Managerial Applications. New York: Simon and Schuster.

Bass, B. M., \& Riggio, R. E. (2006). Transformational Leadership (2nd ed.). New York, NY: Taylor \& Francis Group, LLC.

Bennis, W. (2007). The Challenge of Leadership in the Modern World: Introduction to Special Issues. American Psychologist, 62, 2-5.

https://doi.org/10.1037/0003-066X.62.1.2 
Berson, Y., Shamair, B., Avolio, B. J., \& Popper, M. (2001). The Relationship between Vision Strength, Leadership Style \& Context. The Leadership Quarterly, 12, 53-73. https://doi.org/10.1016/S1048-9843(01)00064-9

Bhargavi, S., \& Yaseen, A. (2016). Leadership Styles and Organizational Performance. Strategic Management Quarterly, 4, 87-117.

Creswell, J. W. (2007). Qualitative Inquiry and Research Design: Choosing among Five Approaches. Thousand Oaks, California: Sage Publications Inc.

Daft, R. L. (2000). Organization, Theory and Design (7th ed.). Thomson Learning USA: South-Western College Publishing.

Deluga, R. J. (1992). The Relationship of Leader-Member Exchange with Laissez Faire, Transactional, Transformational Leadership in Naval Environments. In K. E. Clark, M. B. Clark, \& D. P. Campbell (Eds.), Impact of Leadership (pp. 237-247). Greensboro, NC: Centre of Creative Leadership.

Druskat, V. U., Wolff, S. B., Koman, E. C. S., \& Messer, T. E. (2003). Emotionally Competent Group Norms and Group Effectiveness. In Annual Academy of Management Conference.

Giambatista, R. C. (2004). Jumping through Hoops: A Longitudinal Study of Leader Life Cycle in the NBA. The Leadership Quarterly, 15, 607-624. https://doi.org/10.1016/j.leaqua.2004.07.002

Gill, E. (2014). What Is Laissez-Faire Leadership? How Autonomy Can Drive Success. http://online.stu.edu/laissez-faire-leadership

Hackman, R. P., \& Wageman, R. (2007). Asking the Right Questions about Leadership Discussion and Conclusion. American Psychologist, 61, 1-41. https://doi.org/10.1037/0003-066X.62.1.43

Hambrick, D. C. (2007). Upper Echelons Theory: An Update. Academy of Management Review, 32, 334-343. https://doi.org/10.5465/amr.2007.24345254

Haque, A. U., Faizan, R., Zehra, N., Baloch, A., Nadda, V., \& Riaz, F. (2015). Leading Leadership Style to Motivate Cultural-Oriented Female Employees in IT Sector of Developing Country: IT Sectors' Responses from Pakistan. International Journal of Academic Research in Business and Social Sciences, 5, 280-302.

Haque, A., Faizan, R., \& Cockrill, A. (2017). The Relationship between Female Representation at Strategic Level and Firm's Competitiveness: Evidences from Cargo Logistic Firms of Pakistan and Canada. Polish Journal of Management Studies, 15, 69-81. https://doi.org/10.17512/pjms.2017.15.2.07

Igbaekemen, G. O., \& Odivwri, J. E. (2015). Impact of Leadership Style on Organization Performance: A Critical Literature Review. Arabian Journal of Business and Management Review, 5, 1-7.

Iqbal, N., Anwar, S., \& Haider, N. (2015). Effect of Leadership Style on Employee Performance. Arabian Journal of Business and Management Review, 5, 1-6.

Ismail, A., Halim, F. A., Munna, D. N., Abdullah, A., Shminan, A. S. A., \& Muda, A. L. (2009). The Mediating Effect of Empowerment in the Relationship between Transformational Leadership and Service Quality. Journal of Business Management, 4, 3-12. https://doi.org/10.5539/ijbm.v4n4p3

Javier, J. (2002). A Review Paper on Organizational Culture and Organizational Performance. International Journal of Business and Social Science, 1, 52-76.

Jeremy, M., Melinde, C., \& Ciller, V. (2012). Perceived Leadership Style and Employee Participation in a Manufacturing Company in the Democratic Republic of Congo. African Journal of Business Management, 6, 5389-5398. 
Jyoti, J., \& Bhau, S. (2015). Impact of Transformational Leadership on Job Performance: Mediating Role of Leader-Member Exchange and Relational Identification. SAGE Open, 5, 1-13. https://doi.org/10.1177/2158244015612518

Katz, D., \& Kahn, R. L. (1978). The Social Psychology of Organizations. New York: John Wiley \& Sons.

Khan, S., Asghar, M., \& Zaheer, A. (2014). Influence of Leadership Style on Employee Job Satisfaction and Firm Financial Performance: A Study of Banking Sector in Islamabad Pakistan. Actual Problems in Economics, 155, 374-384.

Klein, A. S., Cooke, R. A., \& Wallis, J. (2013). The Impact of Leadership Styles on Organizational Culture and Firm Effectiveness: An Empirical Study. Journal of Management \& Organization, 19, 241-254. https://doi.org/10.1017/jmo.2013.34

Kotter, J. P. (1995). Leading Change: Why Transformation Efforts Fail. Harvard Business Review, 73, 59-67.

Kotter, J. P., \& Heskett, J. L. (1992). Corporate Culture and Performance. New York: Free Press.

Luftman, J. N. (2004). Managing the Information Technology Resource: Leadership in the Information Age. Upper Saddle River, NJ: Pearson Prentice Hall.

Maritz, D. (1995). Leadership and Mobilizing Potential. Human Resource Management, 10, 8-16.

Maxwell, J. A. (2005). Qualitative Research Design: An Interactive Approach (2nd Ed.). Thousand Oaks, CA: Sage Publications.

McGrath, R. G., \& MacMillan, I. C. (2000). The Entrepreneurial Mindset. Boston, MA: Harvard Business School Press.

Michael, A. (2010). Leadership Style and Organizational Impact. http://www.ala-apa.org

Mullins, L. J. (2000). Management and Organisational Behavior. London: Pitman Publishers.

Ng'ethe, J. M., Namusonge, G. S., \& Iravo, M. A. (2012). Influence of Leadership Style on Academic Staff Retention in Public Universities. International Journal of Business and Social Science, 3, 297-302. http://ijbssnet.com/journals/Vol_3_No_21_November_2012/31.pdf

Ngodo, O. E. (2008). Procedural Justice and Trust: The Link in the Transformational Leadership-Organizational Outcomes Relationship. International Journal of Leadership Studies, 4, 82-100.

Northouse, P. G. (2009). Introduction to Leadership: Concepts and Practice. Thousand Oaks, CA: SAGE.

Nwokocha, I., \& Iheriohanma, E. B. J. (2015). Nexus between Leadership Styles, Employee Retention and Performance in Organizations. European Scientific Journal, 11, 186-209.

Obiwuru, T. C., Okwu, A. T., Akpa, V. O., \& Nwankwere, I. A. (2011). Effects of Leadership Style on Organization Performance: A Survey of Selected Small Scale Enterprises in Ikosi-KetuCouncil Development Area of Lagos State, Nigeria. Australian Journal of Business and Management Research, 1, 100-111.

Owusu-Sekyere, E., Jengre, E., \& Eliasu, A. (2018). Begging in the City: Complexities, Degree of Organization, and Embedded Risks, Hindawi. Child Development Research, 2018, Article ID: 9863410. https://doi.org/10.1155/2018/9863410

Pettinger, R. (2000). Mastering Organisational Behavior. New York: Palgrave.

Puni, A., Ofei, S. B., \& Okoe, A. (2014). The Effect of Leadership Styles on Firm Perfor- 
mance in Ghana. International Journal of Marketing Studies, 6, 177-185.

Ricardo, R., \& Wade, D. (2001). Corporate Performance Management: How to Build a Better Organization through Measurement Driven Strategies Alignment, Butterworth Heinemann.

Rowe, W. G., Cannella Jr., A. A., Rankin, D., \& Gorman, D. (2005). Leader Succession \& Organizational Performance: Integrating the Common-Sense, Ritual Scapegoating \& Vicious-Circle Succession Theories. The leadership Quarterly, 16, 197-219. https://doi.org/10.1016/j.leaqua.2005.01.001

Sadia, A., \& Aman, A. (2018). Transformational Leadership and Organizational Performance; the Mediating Role of Organizational Innovation. SEISENSE Journal of Management, 1, 59-75.

Saleem, H. (2015). The Impact of Leadership Styles on Job Satisfaction and Mediating Role of Perceived Organizational Politics. Procedia-Social and Behavioral Sciences, 172, 563-569. https://doi.org/10.1016/j.sbspro.2015.01.403

Sekaran, U. (2003). Research Methods for Business: A Skill Building Approach (4th ed.). Hoboken, NJ: John Wiley and Sons, Inc.

Senge, P. (1990). The Fifth Discipline: The Art and Practice of the Learning Organization. New York: Doubleday Currency.

Sethuraman, K., \& Suresh, J. (2014). Effective Leadership Styles. International Business Research, 7, 165-172. https://doi.org/10.5539/ibr.v7n9p165

Sofi, M. A., \& Devanadhen, D. K. (2015). Impact of Leadership Styles on Organizational Performance: An Empirical Assessment of Banking Sector in Jammu and Kashmir. IOSR Journal of Business and Management, 17, 31-45.

Sun, R. Y. (2002). The Relationship among the Leadership Style, Organizational Culture and Organizational Effectiveness Based on Competing Value Framework: An Empirical Study for the Institute of Technology in Taiwan. Doctoral Dissertation, Taipei: National Taipei University.

Tummers, L., \& Knies, E. (2016). Measuring Public Leadership: Developing Scales for Four Key Public Leadership Roles. Public Administration, 94, 433-451. https://doi.org/10.1111/padm.12224

Uchenwamgbe, B. B. P. (2013). Effects of Leadership Style on Organizational Performance in Small and Medium Scale Enterprises (SMEs) in Nigeria. European Journal of Business and Management, 5, 53-73.

Vandenberghe, C., \& Bentein, K. (2009). A Closer Look at the Relationship between Effective Commitment to Supervisors and Organizations and Turnover. Journal of Occupational and Organizational Psychology, 82, 331-348. https://doi.org/10.1348/096317908X312641

Vroom, V. H., \& Jago, A. G. (2007). The Role of the Situation in Leadership. American Psychologist, 62, 17-24. https://doi.org/10.1037/0003-066X.62.1.17

Wang, F.-J., Shieh, C., \& Tang, M. (2010). Effect of Leadership Style on Organizational Performance as Viewed from Human Resources Management Strategy. African Journal of Business Management, 14, 3924-3936.

Weber, M. (2009). The Theory of Social and Economic Organization. New York: Simon and Schuster.

Welty Peachey, J., Burton, L. J., \& Wells, J. E. (2014). Examining the Influence of Transformational Leadership, Organizational Commitment, Job Embeddedness, and Job Search Behaviors on Turnover Intentions in Intercollegiate Athletics. Leadership and Organization Development Journal, 35, 740-755. 
https://doi.org/10.1108/LODJ-10-2012-0128

Xenikou, A. (2017). Transformational Leadership, Transactional Contingent Reward, and Organizational Identification: The Mediating Effect of Perceived Innovation and Goal Culture Orientations. Frontiers in Psychology, 8, 1754.

https://doi.org/10.3389/fpsyg.2017.01754

$\mathrm{Xu}$, G. Y., \& Wang, Z. S. (2008). The Impact of Transformational Leadership Style on Organizational Performance: The Intermediary Effects of Leader-Member Exchange (pp. 1090-1097). Long Beach, CA: IEEE Xplore.

Zacharatos, A., Barling, J., \& Kelloway, E. K. (2000). Development \& Effects of Transformational Leadership in Adolescents. The Leadership Quarterly, 11, 211-226.

https://doi.org/10.1016/S1048-9843(00)00041-2 